\title{
Harvesting Microalgal Biomass grown in Anaerobic Sewage Treatment Effluent by the Coagulation-Flocculation Method: Effect of $\mathbf{p H}$
}

\author{
Servio Tulio Cassini ${ }^{1 *}$, Sara Aparecida Francisco ${ }^{1}$, Paulo Wagner Pereira Antunes ${ }^{1}$, \\ Rodrigo Nunes Oss ${ }^{1}$, Regina Keller ${ }^{1}$. \\ ${ }^{1}$ Universidade Federal do Espirito Santo, Environmental Engineering, Vitoria, Espirito Santo, Brasil.
}

\begin{abstract}
Harvesting is a critical step in microalgal biomass production process for many reasons. Among the existing techniques available for harvesting and dewatering microalgal biomass, recovery from aqueous medium by coagulation-flocculation has been the most economically viable process, althoughit is highly dependent on pH. This study aims to assess alternative coagulants compared to the standard coagulant aluminum sulfate for microalgal biomass recovery from anaerobic effluent of domestic sewage treatment. The effluent quality was also analyzed after biomass recovery. Coagulants represented by modified tannin, cationic starch and aluminum sulfate recovered more than $90 \%$ of algae biomass, at concentrations greater than $80 \mathrm{mg} / \mathrm{L}$, in the $\mathrm{pH}$ range 7-10. Cationic starch promoted higher microalgal biomass recovery with a wider $\mathrm{pH}$ range. Powdered seeds of Moringa oleifera and Hibiscus esculentus(okra) gum promoted biomass removal of $50 \%$, only in the acidic range of pH. After sedimentation of the microalgal biomass, the effluents showed a removal of $>80 \%$ for phosphorus and nitrogen values and $>50 \%$ for BOD and COD when using aluminum sulfate, cationic starch and modified tannin as coagulants. Natural organic coagulants in a wide $\mathrm{pH}$ range can replace aluminum sulfate, a reference coagulant in microalgal biomass recovery, without decreasing microalgal biomass harvesting efficiency and the quality of the final effluent.
\end{abstract}

Key words: microalgae, anaerobic effluent, coagulation-flocculation, $\mathrm{pH}$

\footnotetext{
*Author for correspondence: scassini@terra.com.br
} 


\section{INTRODUCTION}

Microalgae is a general, rather than taxonomic, designation generally referring to photosynthetic unicellular microorganisms, with visible growth in water bodies as a major component of phytoplankton. The wide variety of microalgal species include prokaryotic algae (cyanobacteria) and eukaryotic algae, such as diatoms (Bacillariophyta), green algae (Chlorophyta) and red algae (Rhodophyta) ${ }^{1}$.

For microalgalbiomass (MBM) production, microalgae rely on sources of inorganic carbon and other nutrients, which mostly include nitrogen $(\mathrm{N})$ and phosphorus $(\mathrm{P})$. When provided these nutritional requirements, microalgae can be grown in natural water matrices (fresh and marine), synthetic growth media and effluent from domestic sewage or industrial treatment systems ${ }^{2,3}$.

The use of wastewater for microalgal growth provides two significant benefits: the tertiary treatment of effluent at the end of the biomass growth and recovery process, which incorporates the nutrients required by microalgae and generates bulky biomass for many purposes ${ }^{4,5}$. Microalgal biofuels could be an important alternative to conventional biofuels, as microalgae can be produced at high rates without the need of arable land or potable water and with out having competition with food production ${ }^{2}$. In addition to the benefits of microalgal biomass production in the effluent medium, microalgae are able to assimilate $\mathrm{CO}_{2}$ as a carbon source for growth. Approximately 1.6 to $2.0 \mathrm{~g}$ of $\mathrm{CO}_{2}$ can be captured per gram of $\mathrm{MBM}$ produced, thus contributing to a reduction in greenhouse gases ${ }^{6}$.

The energy-intensive harvesting processes are limiting the commercial production of microalgal biofuels and other products that could be commercially viable. Harvesting microalgal biomass from the aqueous media is a critical step for microalgal biomass production because it represents 20 to $50 \%$ of the total cost ${ }^{7,8}$. The main microalgal harvesting processes include filtration, centrifugation, magnetic or electromagnetic separation, coagulation-flocculation, flotation and sedimentation or a combination of these processes. However, despite the abundance of microalgae recovery studies for microalgal biomass recovery, there is no consensus on the most appropriate methodology for this process ${ }^{9,10}$. The coagulation-flocculation process, followed by sedimentation, has been the most widely adopted method because it has been shown to be economically viable for large production volumes of biomass ${ }^{11,12}$. The coagulation-flocculation process can promote microalgal aggregation by the addition of coagulants (electrolytes), which can be metal salts, natural or synthetic polymers, or through $\mathrm{pH}$ adjustment, providing floc formation which facilitates microalgal biomass sedimentation ${ }^{13}$. According to Duan and Gregory ${ }^{14}$, this process is critically dependent on $\mathrm{pH}$ values. Inorganic coagulants are very effective for MBM harvesting, but require a high dosage of coagulant addition, and thus, contaminates the MBM with aluminum and iron. Unlike inorganic metal salts, biodegradable organic coagulants do not contaminate the recovered biomass, and generally require low application doses, considering a wide $\mathrm{pH}$ range. Therefore, coagulants obtained from natural polymers are better alternatives for MBM harvesting than inorganic coagulants ${ }^{15,16,17}$.

In this work, aluminum sulfate wasused as the reference coagulant, and natural organic coagulants were obtained from Moringa oleifera seeds, Acacia tannin, Hibiscus esculentus gum and cationic starch and were evaluated for MBM recovery by thecoagulation-flocculation-sedimentation method. The optimal dose and $\mathrm{pH}$ values were evaluated, which provide the best efficiency rates for recovery of MBM for each polymer. Furthermore, the quality of the effluent after sedimentation of the three best MBM recovered coagulants was assessed. 


\section{MATERIALS AND METHODS}

\section{Microalgal Growth Conditions}

Microalgal growth was performed in effluent media from the anaerobic domestic experimental sewage treatment plant, located at Federal University of Espírito Santo (UFES), Goiabeiras campus, Vitoria, ES, Brazil. The $\mathrm{pH}$, alkalinity, COD, BOD, total phosphorus (TP), and NTK nitrogen (TN) of the anaerobic effluent were analyzed, according to methodologies proposed by the Standard Methods for the Examination of Water and Wastewater ${ }^{18}$, as shown in Table 1.

Table 1 - Averaged values $(\bar{x})$ andcoefficients of variation $(\mathrm{CV})$ of the main parametersevaluated for anaerobic effluentquality $(\mathrm{n}=3)$.

\begin{tabular}{lll}
\hline Parameter & $\overline{\boldsymbol{x}}$ & $\mathbf{C V}(\boldsymbol{\%})$ \\
\hline $\mathrm{pH}$ & 7.8 & 0.5 \\
\hline Alkalinity $(\mathrm{mg} / \mathrm{L} \mathrm{CaCO}$ & 3 \\
\hline $\mathrm{COD}\left(\mathrm{mg} / \mathrm{L} \mathrm{O}_{2}\right)$ & 207 & 2 \\
\hline BOD $\left(\mathrm{mg} / \mathrm{L} \mathrm{O}_{2}\right)$ & 110 & 9 \\
\hline Total Phosphorous $(\mathrm{mg} / \mathrm{L})$ & 66 & 8 \\
\hline Total Nitrogen $(\mathrm{mg} / \mathrm{L})$ & 9.8 & 1.4 \\
\hline
\end{tabular}

The anaerobic effluentwas previously filtered through a sand-gravel filter to remove large particles. The effluent was inoculated with a Chlorella $s p$. strain previously isolated and grown in sewage anaerobic effluent, at a final concentration of $2.0 \times 10^{7}$ cells $/ \mathrm{mL}$. The production of microalgal biomass was conducted in an outdoor batch pilot - scale photobioreactor (FBR), which consisted of a $1.0 \mathrm{~m}^{3}$ plastic tank with an aeration system programmed to operate for 15 minutes, every three hours, and maintained at a temperature of approximately $30^{\circ} \mathrm{C}$ during day time hours.

Optical microscopy images of the main species of microalgae grown in the anaerobic effluent were obtained through optical microscopy (CARL ZEISS Axioplan), using a digital camera (MC80DX) coupled to the equipment, on a $40 \mu \mathrm{m}$ scale.

\section{Coagulation-Flocculation Assays}

The coagulation-flocculation process was performed in jar tests under hydraulic parameters according to Di Bernardo \& Di Bernardo ${ }^{19}$ and Richter ${ }^{20}$. Four alternative coagulants were evaluated (modified tannin Tanfloc ${ }^{\circledR}$ Pop, Moringa oleifera seed powder, Hibiscus esculentus gum and SUPERION ${ }^{\circledR} 300$ cationic starch). The coagulant aluminum sulfate $\left(\mathrm{Al}_{2}\left(\mathrm{SO}_{4}\right)_{3}\right)$ was used as a reference for the microalgal coagulation process.

The SUPERION ${ }^{\circledR} 300$ cationic starch solution was obtained from the mixture of the powder with distilled water at a concentration of $10 \mathrm{~g} / \mathrm{L}$ and solubilized at $60^{\circ} \mathrm{C}$, until the formation of a gelatinous product. Tanfloc ${ }^{\circledR}$ Pop $\left(\right.$ TANAC $\left.^{\odot}\right)$ and aluminum sulfate (Dinamica, $\left.\mathrm{Al}_{2}\left(\mathrm{SO}_{4}\right)_{3} \cdot(14-18) \mathrm{H}_{2} \mathrm{O}\right)$ solutions were established in accordance with the guidelines of the product manufacturer. The dry seeds of M. oleiferawe reprocessed in accordance with the recommendations of Teixeira et al. ${ }^{13}$.Okra (Hibiscus esculentus) gum prepared from raw okra involved the following macrosteps: (1) Raw pods of $H$. esculentus, obtained from a local market, were washed with distilled water, and then, the seeds were removed from the pods, according to Mishra $e t a l .^{21}$. (2) Forgum extraction, the pods were triturated for one minute, with distilled water at $50^{\circ} \mathrm{C}$, in a ratio $1: 7 \mathrm{w} / \mathrm{v}$. After grinding, the contents were filtered as recommended by Pranne \& Tanatcha ${ }^{22}$.(3) The liquid fraction was mixed with ethanol 3:1 v/v and stirred at $150 \mathrm{rpm}$ for an hour. The obtained gum was washed in acetone $1: 1 \mathrm{v} / \mathrm{v}$, stirred at $150 \mathrm{rpm}$ for 20 minutes, and then filtered through a muslin 
fabric vacuum system to remove excess of ethanol and acetone. (4) The solubilized material was placed in distilled water at $65^{\circ} \mathrm{C}$, until the formation of a gelatinous product; this product was used as the okra coagulant.

The coagulation diagrams were created according to the methodology proposed by Paixão ${ }^{23}$ and Di Bernardo \& Di Bernardo ${ }^{19}$, and plotted in the software Surfer ${ }^{\circledR} 11$. The microalgae biomass nutrient removal efficiency was determined by Equation 1, where $\mathrm{E}$ is the removal efficiency in percent, $\mathrm{C}_{0}$ is the value determined for the parameter evaluated, and $\mathrm{C}$ is the concentration of the parameter evaluated in the final effluent after MBM sedimentation.

$\mathrm{E}(\%)=\frac{\mathrm{C}-\mathrm{C}_{0}}{\mathrm{C}} \times 100($ Eq. 1$)$

\section{Microalgal Biomass and Final Effluent Characterization}

MBM characterization was determined by the ratio of volatile solids to total solids VSS/TS, according to Andreoli et al. ${ }^{24}$. The physical-chemical characterization of the final effluent after the separation process was determined by measuring $\mathrm{pH}$, alkalinity, COD, BOD, total phosphorus and NTK nitrogen. All assays were performed in accordance tothe Standard Methods for the Examination of Water and Wastewater ${ }^{18}$.

\section{Statistical Analysis}

Statistical analysis was performed by using an analysis of variance (ANOVA), followed by a Tukey's post hoc test, to determine the significance in differences among the physical-chemical parameter values, with a significance level of $\alpha=$ $5.0 \%$.

\section{RESULTS AND DISCUSSION}

The dominant genera of microalgae naturally associated with the anaerobic effluent were Scenedesmus sp. (Fig. 1A), Chlorella sp.(Fig. 1B) and Synechocystis sp. (Fig. 1C).Additionally, other microorganisms, such as fungi and protozoa, were associated with the anaerobic effluent due to natural growth in the non-sterile medium.

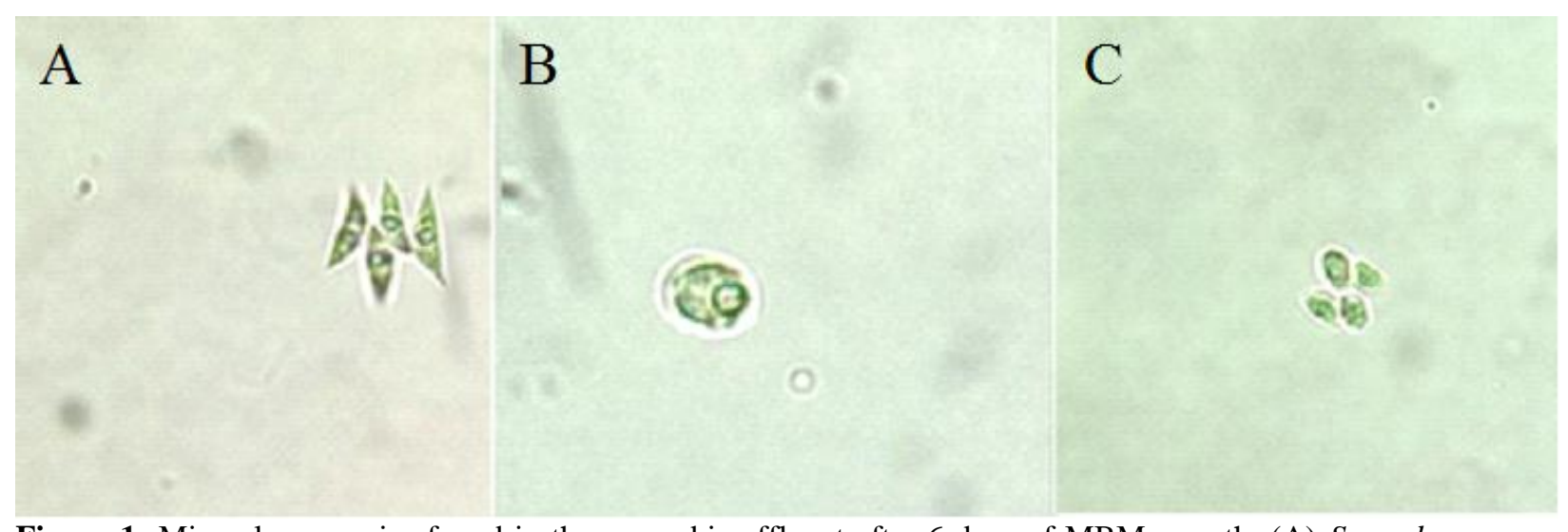

Figure 1 -Microalgae species found in the anaerobic effluent after 6 days of MBM growth: (A) Scenedesmus sp., (B) Chlorella sp., and (C) Synechocystis sp.

In study reported by Torres ${ }^{25}$, six microalgae, identified as Desmodesmus sp., Chlorococcum sp., Coccomyxa sp., Chlorella sp., Scenedesmus sp. and Tetradesmus $s p$., were isolated from a Domestic Sewage Anaerobic Experimental Treatment Plant. Unlike the results of this study, Torres ${ }^{25}$ observed abundant growth of Chlorella $s p$. in the anaerobic effluent, which showed a survival greater than $90 \%$ 
compared to other species. The evaluation of the microalgal growth in a photobioreactor, using previously primary- and secondary-treated effluent from a meat processing industry as the growth medium, was performed in the study by Tango $^{26}$. Similar to the present study, Scenedesmus $s p$. was the dominant microalgae in both evaluated effluents.

The growth of microalgae was dependent on $\mathrm{pH}$ and temperature of the medium, characterized as a daily variation cycle, as shown in Figure 2.

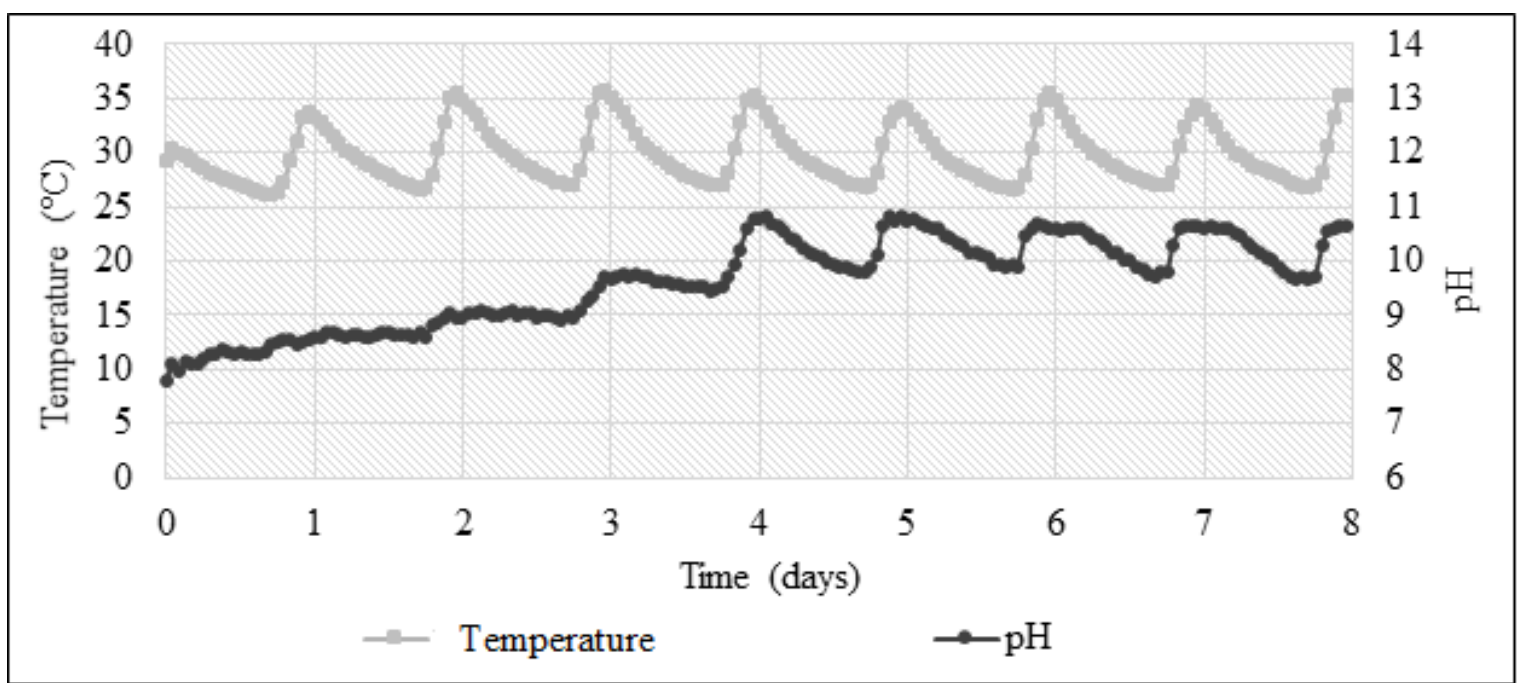

Figure 2 - Daily cycle variation in $\mathrm{pH}$ and temperature of the MBM batch growth over 8 days.

The microalgal biomass growing in culture showed a large variation in $\mathrm{pH}$ values varying from approximately 8 to apeak of 11 over the course of the daily diurnal cycle. Initial $\mathrm{pH}$ values were less variable and after stable growth was achieved by day 4 , the diurnal cycle was fully operating. This could be associated with the $\mathrm{CO}_{2} /$ $\mathrm{CO}_{3}{ }^{2-}$ balance, as seen in Equation 2.

$$
\mathrm{CO}_{2(\mathrm{aq})} \leftrightarrow \mathrm{H}_{2} \mathrm{CO}_{3} \leftrightarrow \mathrm{H}^{+}+\mathrm{HCO}_{3}^{-} \leftrightarrow \mathrm{H}^{+}+\mathrm{CO}_{3}^{2-}
$$

The inorganic carbon species normally used by microalgae are $\mathrm{CO}_{2}$ and $\mathrm{HCO}_{3}^{-}$. The assimilation of $\mathrm{HCO}_{3}^{-}$, assisted by the enzyme carbonic anhydrase, likely represents a true $\mathrm{H}^{+}$removal from water medium and consequently results in anincrease in $\mathrm{pH}$ values. At higher $\mathrm{pH}$ values, e.g., $\mathrm{pH}>9$, most of the inorganic carbon is in form of carbonate $\left(\mathrm{CO}_{3}{ }^{2-}\right)$ which is also used by microalgae in high alkalinity values, resulting in $\mathrm{H}^{+}$removal from water medium and consequently results in an increase in $\mathrm{pH}$. Night respiration and other metabolic processes replenish the $\mathrm{CO}_{2}$ in the medium, lowering the $\mathrm{pH}$ values and restoring the $\mathrm{pH}$ cycle $^{27}$.

Addition or removal of $\mathrm{CO}_{2}$ have no direct effect on the alkalinity, but these processes do affect the $\mathrm{pH}$ and are responsible for the significant diurnal changes in $\mathrm{pH}$. Because of the $\mathrm{pH}$ values observed in the daily cycle of microalgal growth, the choice in coagulant type became a critical factor. Thus, we propose optimized microalgal biomass recover ythrough a coagulation-flocculation mechanism based on the $\mathrm{pH}$ range of the medium. The results of coagulation assays performed with jar tests and plotted by diagrams are shown in Figure 3. 

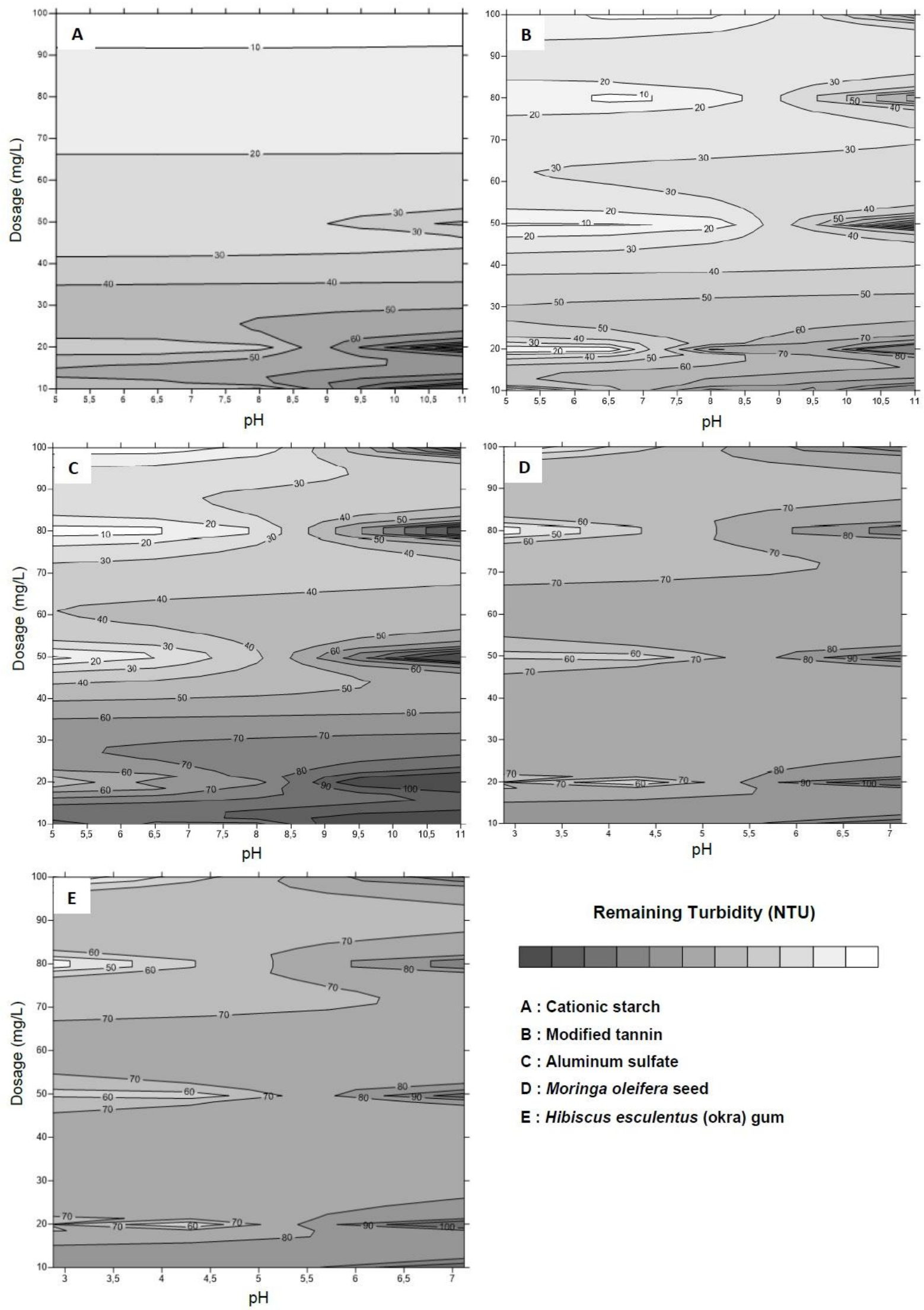

Remaining Turbidity (NTU)

\section{A : Cationic starch \\ B : Modified tannin \\ C : Aluminum sulfate \\ D : Moringa oleifera seed \\ E : Hibiscus esculentus (okra) gum}

Figure3 -Coagulation diagrams based on Jar tests datafor different coagulants. The lightest are as represent lower turbidity values, while the darker areas have the greatest remaining turbidity values. 
Based on the results obtained from the diagrams, it was possible to determine the microalgal biomass (MBM) removal efficiency values, as a function of dose and $\mathrm{pH}$, as recorded in Table 2 .

Table 2. Dose, optimum pH values and MBM removal efficiencies for each coagulant when evaluated by means of the coagulation-flocculation process followed by sedimentation.

\begin{tabular}{llll}
\hline Coagulant & pH & Dose $(\mathbf{m g} / \mathbf{L})$ & Removal efficiency $(\%)$ \\
\hline Aluminum sulfate & 7.0 & 50.0 & 95.9 \\
\hline SUPERION $^{\circledR}$ 300 cationic starch & 10.0 & 80.0 & 92.5 \\
\hline TANFLOC $^{\circledR}$ POP & 9.0 & 100.0 & 95.6 \\
\hline Moringa oleifera seed & 5.0 & 150.0 & 85.8 \\
\hline Hibiscus esculentus (okra) gum & 5.0 & 100.0 & 80.3 \\
\hline
\end{tabular}

From the analysis of the results presented in this study and in the related literature, it could be inferred that aluminum sulfate is an effective coagulant in the recovery of MBM for neutral and acidic $\mathrm{pH}$ ranges, in doses less than $80 \mathrm{mg} / \mathrm{L}$. At basic $\mathrm{pH}$ values, aluminum sulfate reached a biomass recovery of 60 to $70 \%$ with doses higher than $80 \mathrm{mg} / \mathrm{L}$. Efficiencies greater than $90 \%$ were obtained by applying doses greater than $50 \mathrm{mg} / \mathrm{L}$, at neutral $\mathrm{pH}$; however, according to this study, neutral $\mathrm{pH}$ is not within the operating $\mathrm{pH}$ range for microalgal growth. In a study by Teixeira $e t$ al. ${ }^{13}, C$. vulgaris biomass recovery was $93.8 \%$, applying $1000 \mathrm{mg} / \mathrm{L}$ of aluminum sulfate at $\mathrm{pH}$ 9.24. Gerde et al. ${ }^{16}$ applied aluminum sulfate to recover Scenedesmus $s p$. grown in synthetic medium at an adjusted $\mathrm{pH}$ between 8.5 and 9.5. Doses of 250 $\mathrm{mg} / \mathrm{L}$ of aluminum sulfate were required to achieve $90 \%$ of Scenedesmus $s p$. removal by means of coagulation-flocculation. The data presented in the literature corroborate the findings of this study because a high MBM efficiency removal requires higher doses of aluminum sulfate by coagulation-flocculation at high $\mathrm{pH}$.

For doses greater than $80 \mathrm{mg} / \mathrm{L}$ of modified tannin, recovery efficiencies were greater than $80 \%$, with $\mathrm{pH}$ ranging from 7 to 10 . Similar results were obtained to remove Microcystis aeruginosa cultured in BG-11, using a modified tannin coagulant $(\mathrm{Q}-\mathrm{TN})^{28}$. Recovery efficiencies obtained were greater than $90 \%$ in a $\mathrm{pH}$ range from 6 to $9^{28}$. In a recent study, Chlorella vulgaris biomass cultivated in swine effluent treated by phytoremediation had a $97 \%$ removal efficiency rate using 11 $\mathrm{mg} / \mathrm{L}$ of commercial modified tannin at neutral $\mathrm{pH}^{29}$. In a study to recover $C$. vulgaris and Nannochloropsis oculata, grown in synthetic medium with $\mathrm{pH}$ of 8 , the removal efficiencies for $C$. vulgaris were 99,100 and $100 \%$ for concentrations of 5, 15 and $45 \mathrm{mg} / \mathrm{L}$, respectively. In contrast, $N$. oculata removal efficiencies were 92 , 96 and $99 \%$ for concentrations of 5,15 and $45 \mathrm{mg} / \mathrm{L}$, respectively ${ }^{30}$.In this study, the effect of $\mathrm{pH}$ at the same low concentrations of modified tannin $(5,15$ and $45 \mathrm{mg} / \mathrm{L})$, the removal efficiencies were lower, between 30 and $60 \%$. For $\mathrm{pH}$ values of approximately 8 , the MBM recovery from a raceway pond, which treats wastewater, were greater than $90 \%$ by using $50 \mathrm{mg} / \mathrm{L}$ of $\operatorname{Tanfloc}^{\circledR} \mathrm{SG}^{30}$ as the coagulant. In contrast, the same study conditions of Gutierrez et al. ${ }^{31}$ were established in this study efficiency of $96.7 \%$ using Tanfloc ${ }^{\circledR}$ Pop modified tannin as coagulant.

When cationic starch is used as a coagulant in MBM recovery, with doses between 80 and $150 \mathrm{mg} / \mathrm{L}$, the removal efficiencies were above $80 \%$ for a wide range between $\mathrm{pH}$ 7and 11. Two types of cationic starch (GREENFLOC $^{\circledR} 120$ and CARGILL C*BOND RH 35 849) were tested for Parachlorella $s p$. and Scenedesmus $s p$. recovery in astudy by Vandammeet al. $^{32,33}$. With a $\mathrm{pH}$ range between 7 and 8 , than $80 \%$ at cationic GREENFLOC ${ }^{\circledR} 120$ was more efficient in biomass recovery than Cargill C*BOND RH 35849 for both genera of microalgae. The removal efficiency was greater than $80 \%$ for starch doses ranging from 20 to 40 $\mathrm{mg} / \mathrm{L}$ (Parachlorella $s p$.) and $5 \mathrm{mg} / \mathrm{L}$ (Scenedesmus $s p$.); these results corroborate 
those observed in the current study for MBM removal efficiency using the same dosage and $\mathrm{pH}$ ranges. Gerde et al. ${ }^{16}$ used two types of cationic starch (DS02 and DS05) to harvest Scenedesmus sp. and Chlamydomonas reinhardtii in synthetic medium at $\mathrm{pH}$ adjusted between 8.5 and 9.5. The specie Scenedesmus sp. required 20 $\mathrm{mg} / \mathrm{L}$ of DS5 to remove $90 \%$ of the biomass. The specie $C$. reinhardtii required approximately $40 \mathrm{mg} / \mathrm{L}$ of DS2 and $20 \mathrm{mg} / \mathrm{L}$ of DS5 to obtain 85 and $90 \%$ of removal, respectively. Hansel et $a .^{34}$ used modified cationic potato starches for flocculation of Scenedesmus dimorphus cultures. The results showed that all cationic starches were highly effective and the best removal rate used $10 \mathrm{mg} / \mathrm{L}$ of the tested starches, resulting in recovery efficiency above $95 \%$.

According to Vandamme et $a l .^{32,33}$, the cationic starch positive charge is due to quaternary ammonium salts introduced in the manufacturing process, which are able to maintain their positive charge even at high $\mathrm{pH}$ values and can contribute for MBM autoflocculation in higher $\mathrm{pH}$; this may have promoted an increase in the recovery efficiency of BMA at high $\mathrm{pH}$. Furthermore, according to the authors, the efficiency of flocculation by cationic starches and modified tannins can also be related to the degree of substitution of the quaternary groups, the site of substitution and the molecular weight of the polymers.

The use of M. oleifera seed coagulant was not the best option for MBM recovery in this study based on alkaline $\mathrm{pH}$ range. Amaximum removal efficiency of approximately $80 \%$ was achieved by adjusting the $\mathrm{pH}$ to the acidic range (4 to 5) and applying doses of 100 to $150 \mathrm{mg} / \mathrm{L}$ of the M. oleifera seed coagulant. Teixeira et al. ${ }^{13}$ achieved an efficiency of $88.6 \%$ in $C$. vulgaris biomass removal, using WC medium and adjusting the $\mathrm{pH}$ to 9.2 and applying $1000 \mathrm{mg} / \mathrm{L}$ of $M$. oleifera powdered seeds, although the long 2 hours settling time. It should be noted that the selected concentration and settling time in the study by Teixeira et al. ${ }^{13}$ were significantly higher than those observed in the present work. Hamid et al. ${ }^{35}$ obtained efficiencies greater than $95 \%$ for Chlorella sp. removal using a M. oleifera coagulant, but using Bold basal medium, at an approximate $\mathrm{pH}$ value of 6 , and the coagulation process with $30 \mathrm{mg} / \mathrm{L}$ M. oleifer apowdered seeds witha settling time of 2 hours.

Using polymers extracted from okra (H. esculentus) as a coagulant was not adequate for biomass growth in FBR alkaline $\mathrm{pH}$ range as observed in the MBM coagulation diagram charts. Low removal rates were observed in acidic $\mathrm{pH}$ ranges, approximately 4 and 5, reaching efficiencies of up to $80 \%$. There is no sufficient literature data for MBM harvesting studies with microalgae grown in anaerobic sewage treatment effluent, but several studies investigate turbidity removal $\mathrm{pH}$ range domestic sewage effluent treated with polymers extracted from okra. Anastasakis et $a l .{ }^{36}$ presented data ofturbidity removals of 70 to $74 \%$ from biologically treated effluent, applying $2.5 \mathrm{mg} / \mathrm{L}$ of polymers extracted from okra seeds in $\mathrm{pH} 6.09$. In contrast, Agarwal et $a .^{37}$ achieveda suspended solids removal efficiencyof approximately $86 \%$ for raw wastewater treatment, with only $0.12 \mathrm{mg} / \mathrm{L}$ of extracted okra gum at neutral $\mathrm{pH}$.

Modified tannin, aluminum sulfate and cationic starch as coagulants were the most efficient for MBM recovery after the sedimentation process. The consolidated results for three best coagulants for MBM recovery for $\mathrm{pH}$ range of microalgal growth are presented in Table 3. 
Table 3 - Means $(\bar{x})$ and coefficients of variation $(\mathrm{CV} \%)$ of the main parameters for the evaluation of anaerobic effluent used for MBM growth (EUASB) and of the effluents after MBM removal by aluminum sulfate (ESAL), modified tannin (ETFP) and cationic starch (EACS). The different letters on each line indicate significant differences $(\mathrm{p}<0.05)$ by Turkey's test.

\begin{tabular}{|c|c|c|c|c|c|c|c|c|c|}
\hline \multirow{2}{*}{\multicolumn{2}{|c|}{ Parameter }} & \multicolumn{2}{|l|}{ EUASB } & \multicolumn{2}{|l|}{ ESAL } & \multicolumn{2}{|l|}{ ETFP } & \multicolumn{2}{|c|}{ EACS } \\
\hline & & $\bar{x}$ & $\mathrm{CV}(\%)$ & $\bar{x}$ & $\mathrm{CV}(\%)$ & $\bar{x}$ & $\mathrm{CV}(\%)$ & $\bar{x}$ & $\mathrm{CV}(\%)$ \\
\hline $\mathrm{pH}$ & & $7.8^{\mathrm{a}}$ & 0.5 & $3.4^{\mathrm{b}}$ & 4.0 & $4.1^{\mathrm{b}}$ & 14.8 & $7.1^{\mathrm{a}}$ & 1.2 \\
\hline $\begin{array}{l}\text { Alkalinity } \\
\left.\mathrm{CaCO}_{3}\right)\end{array}$ & $(\mathrm{mg} / \mathrm{L}$ & $207^{\mathrm{a}}$ & 2 & $15^{\mathrm{b}}$ & 12 & $15^{\mathrm{b}}$ & 25 & $21^{\mathrm{b}}$ & 9 \\
\hline $\mathrm{BOD}\left(\mathrm{mg} / \mathrm{L} \mathrm{O}_{2}\right)$ & & $66^{\mathrm{a}}$ & 10 & $43^{\mathrm{b}}$ & 2 & $45^{\mathrm{b}}$ & 7 & $21^{\mathrm{c}}$ & 5 \\
\hline $\mathrm{COD}\left(\mathrm{mg} / \mathrm{L} \mathrm{O}_{2}\right)$ & & $110^{\mathrm{a}}$ & 8 & $21^{\mathrm{b}}$ & 29 & $22^{\mathrm{b}}$ & 8 & $11^{\mathrm{b}}$ & 13 \\
\hline $\mathrm{TP}(\mathrm{mg} / \mathrm{L})$ & & $9.8^{\mathrm{a}}$ & 1.4 & $1.3^{\mathrm{b}}$ & 22.5 & $1.4^{\mathrm{b}}$ & 7.5 & $0.9^{\mathrm{b}}$ & 5.1 \\
\hline $\mathrm{TN}(\mathrm{mg} / \mathrm{L})$ & & $37.2^{\mathrm{a}}$ & 6.0 & $3.6^{\mathrm{bc}}$ & 20.8 & $5.4^{\mathrm{b}}$ & 15.8 & $1.8^{\mathrm{c}}$ & 15.8 \\
\hline
\end{tabular}

From the analysis of the main physical-chemical parameters, the results suggest that the effluent $\mathrm{pH}$ values varied significantly after biomass removal and were generally more acidic, except for the effluent after biomass removal with the cationic starch, which provided an effluent with a nearly neutral $\mathrm{pH}$.

The results presented in Table 3 illustrate one of the major advantages of MBM growth in anaerobic sewage treatment effluents: the growth of MBM represents a tertiary sewage treatment, because of the removal of phosphorus and nitrogen from the aqueous phase. The total $\mathrm{P}$ and total $\mathrm{N}$ decrease were more evident after using cationic starch as a coagulant, show in gremoval efficiencies of $90.64 \%$ and $95.14 \%$, respectively. Nutrient removal could be related to the MBM assimilation and the other associated biomass, such as fungi and bacteriaas microalgal growth was not performed in sterile medium.

Interestingly, a decrease in chemical and biochemical oxygen demands (BOD and COD) of $44 \%$ and $84 \%$, respectively, were observed (Table 3 ). The removal of BOD and COD may be related to the removal of the suspended and dissolved organic material with negative charges present in anaerobic sewage treatment effluent (EUASB), microalgal cells and other microorganisms associated with EUASB; therefore, this process decreases the oxygen demand, particularly the chemical oxygen demand (Table 3 ).

Alkalinity is another parameter that showed the same trend with decreasing values as compared to the anaerobic sewage treatment effluent, taking on average by $91 \%$. As mentioned previously, growth medium $\mathrm{pH}$ and alkalinity increasingly coincide with the exponential MBM growth phase; this is a phenomenon that can be explained by the consumption of $\mathrm{CO}_{2}$ for photosynthesis, increasing the concentration of $\mathrm{HCO}_{3}^{-}$ and $\mathrm{CO}_{3}{ }^{2-}$ and consequent rising in $\mathrm{pH}$ and alkalinity from carbonates and bicarbonates. As the culture moves to a lower stage of growth, during which stage the samples were collected for biomass removal, the medium alkalinity slightly reduced due to a reduction in dissolved $\mathrm{CO}_{2}$ consumption.

\section{CONCLUSIONS}

It was possible to very fypolymer dosage, the optimum $\mathrm{pH}$ values and MBM removal efficiencies through the process of coagulation-flocculation followed by sedimentation. It is worth noting that, for high $\mathrm{pH}$ values from 8 to 10 , only the cationic starch and modified tannin coagulants provided optimal MBM removal efficiencies with doses of 80 and $100 \mathrm{mg} / \mathrm{L}$ of the polymers, respectively.

From the analysis of the coagulation diagrams and the biomass removal efficiency data, cationic starch had the lowest dose required with highest recovery efficiency in 
the target $\mathrm{pH}$ range observed for the MBM growth; however, the $\mathrm{pH}$ range of application and recovery efficiencies were similar to those reached using the modified tannin. Aluminum sulfate showed a smaller $\mathrm{pH}$ range for application than the range of modified tannin and cationic starch polymers, and required larger doses to achieve the same MBM recovery efficiency.

M. oleifera seeds and $H$. esculentus (okra) gum promoted MBM removals of only approximately $50 \%$, in the acidic $\mathrm{pH}$ range. With aluminum sulfate, modified tannin and cationic starch as coagulants, the effluents generated after MBM floc settling revealed a total P removal of greater than $80 \%$, and total N, BOD and COD removals were all greater than $50 \%$.

Although aluminum sulfate is commonly used as a reference coagulant in microalgal biomass recovery, this work verified that it can be replaced by natural coagulants (e.g.,modified tannin and cationic starch) under the conditions presented here, without decreasing the biomass removal efficiency and causing negative impacts to the final effluent and, consequently, to the recipient water bodies.

\section{ACKNOWLEDGMENTS}

This work was completed under the Biogas Project. Authors are thankful to Department of Environmental Engineering Master's program for their support. The authors also gratefully acknowledge the financial support and scholarship of FINEP/UFES and CNPq, respectively.

\section{REFERENCES}

1 Bicudo CEM, Menezes M. Gênero de algas continentais brasileiras (chave de identificação e descrição). $2^{a}$ ed. São Carlos: RIMA; 2005.

2 Mata TM, Martins AA, Caetano NS. Microalgae for biodiesel production and other applications: A review. Renew Sust Energ Rev. 2010 jul; 14:217-232.

3 Fakir K, Yaakob K, Ali E, Abdullah SRS, Takriff MS. An overview of microalgae as a wastewater treatment. AMMAN, Jordan International Energy Conference; 2011.

4 Kunjapur AM, Eldridge RB. Photobioreactor design for commercial biofuel production from microalgae. J Ind Chem Eng. 2010 mar; 49(8):3516-3526.

5 Mahapatra DM, Chanakya HN, Ramachandra TV. Bioremediation and lipid synthesis through mixotriphic algal consortia in municipal wastewater. Bioresource Technol. 2014 apr; 168:142-150.

6 Zeng X, Danquah MK, Chen XD, Lu, Y. Microalgae bioengineering: from $\mathrm{CO}_{2}$ fixation to biofuel production. Renew Sust Energ Rev. 2011 apr; 15:3252-3260.

7 Grima EM, Belarbia EH, Fernández FGA, Medinaa AR, Chisti Y. Recovery of microalgal biomass and metabolites: process options and economics. Biotechnol Adv. 2003 oct; 20:557-577.

8 Greenwell HC, Laurens ML, Shields RJ, Lovitt RW, Flynn KJ. Placing microalgae on the biofuels priority list: a review of the technological challenges. J R Soc Interface. 2010 mar; 7:703-726.

9 Milledge JJ, Heaven S. A review of the harvesting of microalgae for biofuel production. Rev Environ Sci Biotechnol. 2013 oct; 12(2):165-178.

10 Castrillo M, Lucas-Salas LM, Rodríguez-Gil C, Martínez D. High pH-induced flocculation-sedimentation and effect of supernatant reuse on growth rate and lipid productivity of Scenedesmus obliquus and Chlorella vulgaris. Bioresource Technol. 2013 nov; 128:324-329.

11 Uduman N, Qi Y, Danquah MK, Forde GM, Hoadley A. Dewatering of microalgal cultures: A major bottleneck to algae-based fuels. J Renew and Sustain Energ. 2010; 2:115. 
12 Granados MR, Acien FG, Gomez C, Fernandez-Sevilla JM, Grima EM. Evaluation of flocculants for the recovery of freshwater microalgae. Bioresource Technol. 2012 may; 118:102-110.

13 Teixeira CMLL, Kirsten KV, Teixeira PCN. Evaluation of Moringa oleifera seed flour as a flocculating agent for potential biodiesel producer microalgae. J Appl Phycol. 2012 jan; 24:557-563.

14 Duan J, Gregory, J. Coagulation by hydrolysing metal salts. Adv Colloid Interfac. 2003; 100: 475-502.

15 Wan C, Alam A, Zhao X, Zhang X, Guo S, Ho S, et al. Current progress and future prospect of microalgal biomass harvest using various flocculation technologies. Bioresource Technol. $2015 \mathrm{dec}$; 184:251-257.

16 Gerde JA, Yao L, Lio J, Wen Z, Wang T. Microalgae flocculation: Impact of flocculant type, algae species and cell concentration. Algal Research. 2014 dec; 3:30-35.

17 Baptista ATA, Coldebella PF, Cardines PHF, Gomes RG, Vieira, MF, Bergamasco F, Vieira AMS. Coagulation-flocculation process with ultrafiltered saline extract of Moringa oleifera for the treatment of surface water. Chem Eng J. 2015; 276: 166-173.

18 American Public Health Association (APHA). Standard Methods for Examination of Water and Wasterwater. 16 a ed. USA: APHA. 1985. 1527p.

19 Di Bernardo L, Di Bernardo A, Centuione Filho PL. Ensaios de Tratabilidade de Água e dos Resíduos Gerados em Estações de Tratamento de Água. $1^{a}$ ed. São Carlos: RIMA; 2002.

20 Richter CA. Água: Métodos e tecnologia de tratamento. $1^{\mathrm{a}}$ ed. São Paulo: Editora Blucher; 2009.

21 Misra R, Guldhe A, Singh P, Rawat I, Bux F. Electrochemical harvesting process for microalgae by using nonsacrificial carbon electrode: A sustainable approach for biodiesel production. Chem Eng J. 2014 jun; 255:327-333.

22 Pranee A, Thanatcha R. Extraction and characterization of mucilage in Ziziphus mauritiana Lam. Int Food Res J. 2011; 18:201-212.

23 Paixão GC. Estudo da coagulação-floculação-sedimentação de água com turbidez ou cor elevada, utilizando polímero sintético como auxiliar de floculação [Dissertação de Mestrado]. São Carlos: Escola de Engenharia de São Carlos, Engenharia Hidráulica e Saneamento; 1996.

24 Andreoli CV, Von Sperling M, Fernandes F. Lodo de esgoto: tratamento e disposição final. $2^{\mathrm{a}}$ ed. Belo Horizonte: Editora UFMG; 2001.

25 Torres HSJ. Cultivo de microalgas em efluente de tratamento anaeróbio de esgoto [Tese de Doutorado]. Vitória: Universidade Federal do espírito Santo, Engenharia Ambiental; 2015.

26 Tango MD. Cultivo de microalgas em efluentes da indústria de beneficiamento de carnes em fotobiorreator do tipo coluna de bolhas [Dissertação de Mestrado]. Viçosa: Universidade Federal de Viçosa, Engenharia Civil; 2015.

27 Sutherland DL, Howard-Williams C, Turnbull MH, Broady PA, Craggs RJ. The effects of $\mathrm{CO} 2$ addition along a $\mathrm{pH}$ gradiente on wastewater microalgal photo-physiology, biomass production and nutriente removal. Water Res. 2015; 70: 9-26.

28 Wang L, Liang W, Yu J, Liang Z, Ruan L, Zhang Y. Flocculation of Microcystis aeruginosa Using Modified Larch Tannin. Environ Sci Technol. 2013 may; 47:57715777.

29 Mezzari MP, Silva MLB, Pirolli M, Perazzoli S, Steinmetz RLR, Nunes EO, et al. Assessment of a tannin-based organic polymer to harvest Chlorella vulgaris biomass from swine wastewater digestate phycoremediation. Water Sci Technol. 2014; 70(5):888894.

30 Roselet F, Vandamme D, Roselet M, Muylaert K, Abreu PC. Screening of comercial natural and synthetic cationic polymers for flocculation of freshwater and marine microalgae and effects of molecular weight and charge density. Algae Research. 2015 may; 10:183-188.

31 Gutiérrez R, Passos F, Ferrer I, Uggetti E, García J. Harvesting microalgae from wastewater treatment systems with natural flocculants: Effect on biomass settling and biogas production. Algal Research. 2015; 9:204-211. 
32 Vandamme D, Foubert I, Muylaert K, Meesschaert B. Flocculation of microalgae using cationic starch. J Appl Phycol. 2010 nov; 22:525-530.

33 Vandamme D, Foubert I, Muylaert K. Flocculation as a low-cost method for harvesting microalgae for bulk biomass production. Trends Biotechnol. 2013 apr; 31(4): 233-239.

34 Hansel PA, Riefler RG, Stuart BJ. Efficient flocculation of microalgae for biomass production using cationic starch. Algal Research. 2014 aug; 5:133-139.

35 Hamid SHA, Lananan F, Din WNS, Lam SS, Khatoon H, Endut A, et al. Harvesting microalgae, Chlorella sp., by bio-flocculation by Moringa oleifera seed derivatives from aquaculture wastewater phytoremediation. Int Biodeter Biodegr. 2014 jul; 95:270-275.

36 Anastasakis K, Kalderis D, Diamadopoulos E. Flocculation behavior of mallow and okra mucilage in treating wastewater. Desalination. 2009 oct; 249:786-791.

37 Agarwal M, Srinivasan R, Mishra A. Study on Flocculation Efficiency of Okra Gum in Sewage Waste Water. Macromol Mater Eng. 2001; 286:560-563.

Received: February 03, 2016; Accepted: July 14, 2016 